\title{
Online Education Status at Dental Colleges During COVID-19 Pandemic in Nepal Shrestha RM, ${ }^{1}$ Shrestha $S,{ }^{2}$ Acharya $A,{ }^{1}$ Gupta $A^{1}$
}

${ }^{1}$ Department of Orthodontics,

${ }^{2}$ Department of Community \& Public Health Dentistry,

Kantipur Dental College,

Basundhara, Kathmandu, Nepal.

\section{Corresponding Author}

Rabindra Man Shrestha

Department of Orthodontics,

Kantipur Dental College,

Basundhara, Kathmandu, Nepal.

E-mail: rabindraortho@gmail.com

\section{Citation}

Shrestha RM, Shrestha S, Acharya A, Gupta A. Online Education Status at Dental Colleges During COVID-19 Pandemic in Nepal. Kathmandu Univ Med J. 2020;COVID-19 Special Issue 70(2):15-20.

\begin{abstract}
Background

The COVID-19 pandemic has caused lockdown situation impeding all educational institutions including dental colleges. The circumstance demanded online classes as the alternative strategy for continuation of education.
\end{abstract}

\section{Objective}

To assess current practice and perception about online education among faculties of dental colleges in Nepal.

\section{Method}

A cross-sectional study was conducted among 208 faculties of all dental colleges in Nepal. Data collection was done through structured online questionnaire comprising demographic information, practice and perception of the respondents towards online education. Descriptive statistics surveyed the frequency distribution and Chisquare test assessed the difference in perception among the faculties of different universities.

\section{Result}

The response rate was $74.3 \%$. Faculties commonly used PowerPoint presentation (96.6\%) on Zoom platform (83.3\%) using laptop (94.7\%) with Wi-Fi connection (91.8\%). Majority of faculties had good or satisfactory access to internet (94.8\%). The faculties believed that the online class environment was interactive (95.2\%); but it was not effective (86.5\%) as live classroom. Majority of the faculties (79.4\%) felt tracking of students' presence was difficult. There was no significant difference on perception towards online class among the faculties of Kathmandu University, Tribhuvan University and BP Koirala Institute Health Sciences at $p<0.05$.

\section{Conclusion}

The COVID-19 pandemic has paved the way for e-learning in dental education in Nepal. Faculties agree to complete the theory syllabus and conduct sessional exams as an alternative during the lockdown period. However, they show strong reservations in carrying out practical/clinical simulations and university exams online. Training on e-learning and institutional strategy for online education is recommended.

\section{KEY WORDS}

Dental college, Faculty members, Online education, Pandemic, Perception, Practice 


\section{INTRODUCTION}

The Coronavirus disease (COVID-19) has caused global public health emergency and pandemic. To combat the situation, the Government of Nepal declared lockdown to limit daily outdoor activities, which impeded all educational institutions including dental colleges. The universities suspended all educational activities as precautionary measures. The pandemic situation demanded alternative strategies for the propagation of education. UNICEF recommended the use of online or e-learning approach in educational institutions and suggested the faculties to conduct periodic remote follow-up with the students. ${ }^{1}$

Nepali universities instructed the affiliated dental colleges to start online class. Subsequently, dental colleges of Kathmandu University, Tribhuvan University and BP Koirala Institute of Health Sciences commenced online classes to Bachelor of Dental Surgery (BDS) students. Rimal et al. mentioned that the Nepali medical institutions swiftly embraced the concept of online education to continue the educational activities that would prevent delay of the session. ${ }^{2}$ However, there are challenges with e-learning in a developing country like Nepal; such as IT infrastructure, faculty's competencies and their training/support, students' access to computer/internet, conducive home environment for e-learning etc. ${ }^{3}$

The estimated 400 faculties of fourteen dental colleges in Nepal are believed to be taking online classes through various modalities during the pandemic. Thus, it is imperative to assess the status of online education regarding the internet use, online platform, mode of presentation, students' participation, evaluation, etc. The present study assesses Nepali dental college faculty's current practice of online classes and their perception about this education system.

\section{METHODS}

The present study was cross-sectional questionnairebased; conducted among the faculties of all fourteen dental colleges of Nepal. The self-administered questionnaire was issued online to accessible 300 faculties. The convenient sampling method was used. The sample size was based on the finite number of dental faculties in Nepal and was determined as 182 using the following formula: ${ }^{4}$

$\mathrm{n}=\left[\mathrm{Z}^{2} \mathrm{pq} / \mathrm{e}^{2}\right] /\left[1+\mathrm{Z}^{2} \mathrm{pq} / \mathrm{e}^{2} \times \mathrm{N}\right]$

(Where, $p=36 \%, N=376, e=0.05$ )

The dental faculties involved in online teaching of BDS students, who were willing to participate were included in the study. The study was conducted during May-July 2020. Ethical clearance was taken from Institutional Review Committee (KDC-IRC No. 15/020). Consent statement was mentioned in the questionnaire and was agreed by the participants.
Data collection was done using structured online questionnaire developed on Google Forms issued through various social networking sites. The questionnaire comprised of sections on demographic information, practice on use of online modalities and perception of the respondents on online education. The multiple choices were given for questions on practice section. The perception section comprised of question statements with 4-likert structured answers ranging from 'strongly agree', 'agree', 'disagree' and 'strongly disagree'.

Data management was done through self generated Excel sheet made with Google Forms, which was transferred to SPSS Version 20 for analysis. Descriptive statistics were calculated for frequency distribution. Comparison was done to assess the difference in perception among three different universities using Chi-square test. The level of significance was set at $p<0.05$.

\section{RESULTS}

Among the total of 300 questionnaires sent, 223 faculties responded (response rate $74.3 \%$ ). Among all respondents, only 208 faculties were taking online class during the study period. The rest were excluded from the study. There were 120(57.7\%) male and $88(42.3 \%)$ female respondents. According to the academic level, 19(9.1\%) were Professor, 57(27.4\%) were Associate professor, 56(26.9\%) were Assistant professor, and 76(36.5\%) were Lecturer.

The distribution of samples according to the subject was Conservative dentistry and endodontics $21(10.1 \%)$, Oral medicine and radiology $8(3.8 \%)$, Oral pathology/ biology $12(5.8 \%)$, Oral surgery $16(7.7 \%)$, Orthodontics 35(16.8\%), Periodontics 16(7.7\%), Pedodontics 10(4.8\%), Prosthodontics $25(12 \%)$, Community and public health dentistry 9(4.3\%), Basic sciences 47(22.6\%), Medical science $9(4.3 \%)$. The distribution of samples according to the institution is given in figure 1.

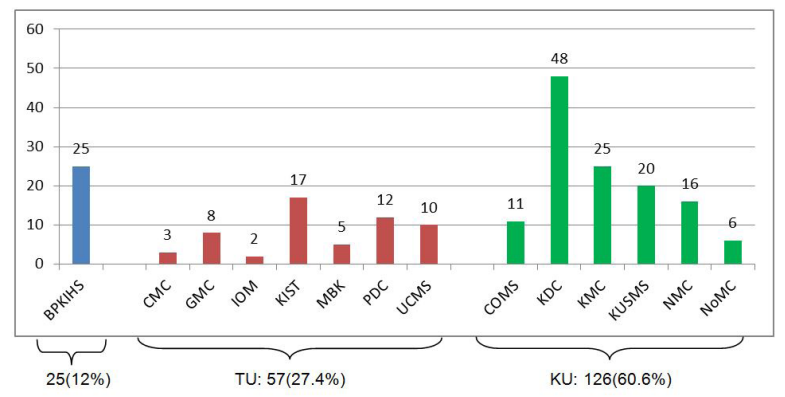

Figure 1. Distribution of samples according to the institution ( $\mathrm{N}=\mathbf{2 0 8 )}$

(BPKIHS: BP Koirala Institute of Health Sciences-Dharan, CMC:Chitwan Medical College-Bharatpur, GMC:Gandaki Medical College-Pokhara, IOM: Institute of Medicine-Kathmandu, KIST:KIST Medical College-Lalitpur, MBK:MB Kedia Dental College-Birgunj, PDC:People's Dental CollegeKathmandu, UCMS:Universal College of Medical Sciences-Bhairahawa, COMS:College of Medical Sciences-Bharatpur, KDC:Kantipur Dental College-Kathmandu, KMC:Kathmandu Medical College-Bhaktapur, KUSMS:KU School of Medical Sciences-Dhulikhel, NMC:Nepal Medical College-Kathmandu, NoMC:Nobel Medical College-Biratnagar) 
According to the present study, 91.8\% Nepali dental faculties had not conducted online class before COVID-19 pandemic and $90.3 \%$ have not received any training for online education. During the lockdown period, $80.3 \%$ conducted online class from home (Table 1).

Table 1. Responses on exposure to online education $(\mathbf{N}=\mathbf{2 0 8})$

\begin{tabular}{|c|c|c|}
\hline \multirow[t]{2}{*}{ Question } & \multicolumn{2}{|c|}{ Response } \\
\hline & Yes & No \\
\hline $\begin{array}{l}\text { Have you ever attended any online } \\
\text { class before Covid-19 pandemic? }\end{array}$ & $106(51 \%)$ & $102(49 \%)$ \\
\hline $\begin{array}{l}\text { Have you ever conducted online class } \\
\text { before Covid-19 pandemic? }\end{array}$ & $17(8.2 \%)$ & 191(91.8\%) \\
\hline $\begin{array}{l}\text { Have you ever received any training for } \\
\text { online education? }\end{array}$ & $20(9.6 \%)$ & 188(90.3\%) \\
\hline $\begin{array}{l}\text { Did you give orientation to the stu- } \\
\text { dents about online education? }\end{array}$ & $133(63.9 \%)$ & $75(36.1 \%)$ \\
\hline $\begin{array}{l}\text { Did you take online class from home } \\
\text { during the lock-down period? }\end{array}$ & $167(80.3 \%)$ & $41(19.7 \%)^{*}$ \\
\hline
\end{tabular}

Regarding the faculties' practice of online class; majority of the faculties used laptop (94.7\%) as the device with the network connection to wireless Wi-Fi system (91.8\%). According to the respondents, the status of internet connection was good in $58.7 \%$ and satisfactory in $36.1 \%$. The most commonly used online platform was Zoom (83.2\%) followed by Dudal (8.2\%), Google Meet (4.8\%). Most of faculties (96.6\%) delivered lectures with the help of Microsoft PowerPoint presentation, while only $1.9 \%$ took verbal lectures online. The online class was administered by faculty themselves in $66.3 \%$ cases, while $29.8 \%$ were assisted by institute's IT personnel. For collecting the assignment, $35.1 \%$ faculty used email, $20.2 \%$ faculty checked assignment during the online class, while $35.6 \%$ faculties do not give any online assignment. According to the present study, $76.4 \%$ faculties provided feedback to the students about their performance, while $24.5 \%$ faculties rarely or do not give feedback (Table 2).

Regarding the faculties' perception on online class environment; $95.2 \%$ faculties believed that the online class is interactive; contrarily $86.5 \%$ did not believe it is effective. Likewise, $77.9 \%$ did not feel online class is distracting; while 79.4\% found tracking the students' presence is difficult during the online classes. Regarding the course syllabus and evaluation; $74.6 \%$ faculty believed that theory syllabus can be completed through online, however only $19.2 \%$ thought that demonstration of practical/clinical simulation is possible through online. $50 \%$ faculties believed it is possible to conduct class test or sessional exam through online, however only $16.3 \%$ agreed that university board exam should be taken online (Table 3 ). The present study found no statistical difference between the faculties of three different universities on perception towards online class at $p<0.05$ (Table 4).
Table 2. Responses on practice of online class during COVID-19 pandemic

\begin{tabular}{|c|c|c|c|c|}
\hline \multirow{3}{*}{$\begin{array}{l}\text { Question } \\
\text { Online class was } \\
\text { called by }\end{array}$} & \multicolumn{4}{|c|}{ Choices } \\
\hline & University & College & Students & Myself \\
\hline & $62(29.8 \%)$ & $132(63.5 \%)$ & $4(1.9 \%)$ & $10(4.8 \%)$ \\
\hline \multirow{2}{*}{$\begin{array}{l}\text { Number of on- } \\
\text { line class taken } \\
\text { per week }\end{array}$} & $1-2$ class & 3-4 class & $5-6$ class & $>6$ class \\
\hline & $128(61.5 \%)$ & $65(31.3 \%)$ & $11(5.3 \%)$ & $4(1.9 \%)$ \\
\hline \multirow{2}{*}{$\begin{array}{l}\text { Attendance } \\
\text { of students in } \\
\text { online class }\end{array}$} & $>90 \%$ & $80-89 \%$ & $70-79 \%$ & $<70 \%$ \\
\hline & $149(71.6 \%)$ & $37(17.8 \%)$ & $9(4.3 \%)$ & $13(6.3 \%)$ \\
\hline \multirow[t]{2}{*}{$\begin{array}{l}\text { Device used for } \\
\text { online class }\end{array}$} & Laptop & Desktop & $\begin{array}{l}\text { Smart- } \\
\text { phone }\end{array}$ & Tablet \\
\hline & $197(94.7 \%)$ & $3(1.4 \%)$ & $6(2.9 \%)$ & $2(1.0 \%)$ \\
\hline \multirow[t]{2}{*}{$\begin{array}{l}\text { Connection for } \\
\text { internet }\end{array}$} & Wi-Fi & Landline & $\begin{array}{l}\text { Cellular } \\
\text { data }\end{array}$ & Others \\
\hline & 191(91.8\%) & $14(6.7 \%)$ & $3(1.4 \%)$ & 0 \\
\hline \multirow[t]{2}{*}{$\begin{array}{l}\text { Status of inter- } \\
\text { net connection }\end{array}$} & Good & Satisfactory & Bad & $\begin{array}{l}\text { Disturbed } \\
\text { due to } \\
\text { electricity }\end{array}$ \\
\hline & $122(58.7 \%)$ & $75(36.1 \%)$ & $2(1 \%)$ & $9(4.3 \%)$ \\
\hline \multirow{2}{*}{$\begin{array}{l}\text { App/ platform } \\
\text { used for online } \\
\text { class }\end{array}$} & Zoom & Dudal & $\begin{array}{l}\text { Google } \\
\text { Meet }\end{array}$ & Others* \\
\hline & $173(83.2 \%)$ & $17(8.2 \%)$ & $10(4.8 \%)$ & $8(3.8 \%)$ \\
\hline \multirow{2}{*}{$\begin{array}{l}\text { Mode of pre- } \\
\text { sentation }\end{array}$} & PowerPoint & Verbal & PDF & Keynote \\
\hline & $201(96.6 \%)$ & $4(1.9 \%)$ & $2(1 \%)$ & $1(0.5 \%)$ \\
\hline \multirow[t]{2}{*}{$\begin{array}{l}\text { Online class ad- } \\
\text { ministered by }\end{array}$} & Myself & $\begin{array}{l}\text { Institute IT } \\
\text { personnel }\end{array}$ & $\begin{array}{l}\text { Student } \\
\text { represen- } \\
\text { tative }\end{array}$ & Others \\
\hline & $138(66.3 \%)$ & $62(29.8 \%)$ & $8(3.8 \%)$ & 0 \\
\hline \multirow[t]{2}{*}{$\begin{array}{l}\text { Collection of } \\
\text { assignment is } \\
\text { through }\end{array}$} & $\begin{array}{l}\text { Online } \\
\text { class }\end{array}$ & Email & $\begin{array}{l}\text { Other } \\
\text { sources\# }\end{array}$ & $\begin{array}{l}\text { Assign- } \\
\text { ment not } \\
\text { given }\end{array}$ \\
\hline & $42(20.2 \%)$ & $73(35.1 \%)$ & $19(9.1 \%)$ & $74(35.6 \%)$ \\
\hline \multirow[t]{2}{*}{$\begin{array}{l}\text { Feedback given } \\
\text { to the students }\end{array}$} & Always & Mostly & Rarely & $\begin{array}{l}\text { Feedback } \\
\text { not given }\end{array}$ \\
\hline & $46(22.1 \%)$ & $113(54.3 \%)$ & $30(14.4 \%)$ & $19(9.1 \%)$ \\
\hline
\end{tabular}

* Google Classroom 3, Microsoft Team 2, Ding Talk 1, Abhyas 1, Cisco Webex 1

\# Google Classroom 9, Viber 7, What's app 2, Ding Talk 1

\section{DISCUSSION}

WHO declared COVID-19 as 'public health emergency of international concern' on January 30 and later called it 'pandemic' on March 11, 2020.5 The Government of Nepal declared nationwide lockdown on March 24. Dental colleges suspended all regular classroom activities, clinical postings and examinations. Universities later appealed affiliated colleges to start online class to the BDS students. Subsequently, online classes commenced at KU on April 11, BPKIHS on April 26; and TU in June $2020 .^{6}$

According to the present study, more than $90 \%$ dental faculties had not conducted online class and did not receive any training for online education before COVID-19 pandemic. Faculties suggested e-learning to incorporate in the syllabus for curricular development of online 
Table 3. Responses on perception of online class during COVID-19 pandemic

\begin{tabular}{lllll}
\hline Statement about online class & Strongly agree & Agree & Disagree & Strongly disagree \\
\hline More effective than conventional class & $4(1.9 \%)$ & $24(11.5 \%)$ & $134(64.4 \%)$ & $46(22.1 \%)$ \\
\hline Online class is interactive & $81(38.9 \%)$ & $117(56.3 \%)$ & $10(4.8 \%)$ & 0 \\
\hline Tracking of student is difficult & $49(23.6 \%)$ & $116(55.8 \%)$ & $40(19.2 \%)$ & $3(1.4 \%)$ \\
\hline Online class environment is distracting & $4(1.9 \%)$ & $42(20.2 \%)$ & $134(64.4 \%)$ & $28(13.5 \%)$ \\
\hline Theory syllabus can be completed through online & $28(13.5 \%)$ & $127(61.1 \%)$ & $49(23.6 \%)$ & $4(1.9 \%)$ \\
\hline Practical simulation exercise is possible & $3(1.4 \%)$ & $37(17.8 \%)$ & $100(48.1 \%)$ & $68(32.7 \%)$ \\
\hline Class test/ sessional exam is possible through online & $8(3.8 \%)$ & $96(46.2 \%)$ & $87(41.8 \%)$ & $17(8.2 \%)$ \\
\hline University exam is possible through online & $5(2.4 \%)$ & $29(13.9 \%)$ & $121(58.2 \%)$ & $53(25.5 \%)$ \\
\hline Online class routine should be incorporated in syllabus & $17(8.2 \%)$ & $124(59.6 \%)$ & $55(26.4 \%)$ & $12(5.8 \%)$ \\
\hline Faculty training is required for online education & $63(30.3 \%)$ & $125(60.1 \%)$ & $20(9.6 \%)$ & 0 \\
\hline Dedicated online package is required for online education & $101(48.6 \%)$ & $98(47.1 \%)$ & $6(2.9 \%)$ & $3(1.4 \%)$
\end{tabular}

Table 4. Comparison of universities on perception towards online class (in percentage)

\begin{tabular}{|c|c|c|c|c|c|c|c|}
\hline \multirow[t]{2}{*}{ Statement about online class } & \multicolumn{2}{|c|}{ BPKIHS ( $n=25)$} & \multicolumn{2}{|c|}{ TU $(n=57)$} & \multicolumn{2}{|c|}{ KU $(n=126)$} & \multirow[t]{2}{*}{ p-Value* } \\
\hline & Agree & Disagree & Agree & Disagree & Agree & Disagree & \\
\hline More effective & 20 & 80 & 19.3 & 80.7 & 9.5 & 90.5 & 0.119 \\
\hline Interactive & 92 & 8 & 96.5 & 3.5 & 95.2 & 4.8 & 0.681 \\
\hline Student tracking is difficult & 80 & 20 & 75.4 & 24.6 & 81 & 19 & 0.692 \\
\hline Class environment is distracting & 32 & 68 & 21.1 & 78.9 & 20.6 & 79.4 & 0.446 \\
\hline Theory syllabus can be completed & 64 & 36 & 75.4 & 24.6 & 76.2 & 23.8 & 0.434 \\
\hline Practical simulation is possible & 36 & 64 & 19.3 & 80.7 & 15.9 & 84.1 & 0.066 \\
\hline Internal exam is possible & 52 & 48 & 52.6 & 47.4 & 48.4 & 51.6 & 0.850 \\
\hline University exam is possible & 28 & 72 & 15.8 & 84.2 & 14.3 & 85.7 & 0.236 \\
\hline Syllabus should incorporate online routine & 84 & 16 & 63.2 & 36.8 & 66.7 & 33.3 & 0.162 \\
\hline Faculty training is required & 96 & 4 & 91.2 & 8.8 & 88.9 & 11.1 & 0.528 \\
\hline Dedicated online package is required & 96 & 4 & 98.2 & 1.8 & 94.4 & 5.6 & 0.502 \\
\hline
\end{tabular}

* Not significant for any category

Agreement: Agree/ strongly agree, Disagreement: Disagree/ strongly disagree

education. They sought the requirement of training and dedicated online package for effective teaching/learning. In a European survey on educational management of COVID-19 crisis, $90 \%$ of dental schools reported using online pedagogical software tools, $72 \%$ used live or streamed videos, $48 \%$ provided links to further online materials, 65\% participated in virtual meetings or journal clubs. ${ }^{7}$ Currently, in Nepal and neighboring countries, Zoom is the most commonly used platform for online education, probably because it is free and user-friendly.

The Zoom platform facilitate presentations on screenshare and small group discussions, which can be linked with other tools like Twitter, Facebook. ${ }^{8}$ Nepali dental faculties are not found to have used Moodle platform, which is extensively used by educational institutes worldwide. It is possible to send didactic materials, conduct forum discussion, organize tasks, assessments, and facilitate personal communication on Moodle. ${ }^{9}$ Even in low-income places, Moodle facilitated formative question formats, e-assessments and assessed skill levels. Students were found to have positive impressions despite technical difficulty. ${ }^{10}$
In this regard, Kathmandu University organized an online training course on 'Moodle application' for faculties of affiliated colleges in July 2020. Dahal et al. had suggested the use of Moodle learning management system; which is designed for pedagogical workshop activity. ${ }^{11}$ The tool utilizes the steps of planning, intervening, information sharing, developing analytical and evaluation skills. It engages the students in the process of learning. Pangeni et al. urged that, Nepali higher education institutions are already late to address the growing educational demand of new generation that needs the culture of online learning. ${ }^{12}$

More than 95\% Nepali faculties' perceive online class environment as interactive and more than $75 \%$ feel it is not distracting. However only $13.4 \%$ believe online class is more effective than the live classroom lectures. Another study among Nepali nursing faculties accepted that, online classes are not fully effective and they are distracting. ${ }^{13}$ According to the present study, faculties register about $90 \%$ students having more than $80 \%$ attendance, contrarily the faculties feel student tracking is difficult during the online class. The virtual class environment might possibly 
engage them in other activities or be inattentive during the online lecture. This problem could be minimized by having interactive question-answer sessions, quizzes, brainstorming, and by engaging the students on topic. ${ }^{14}$

According to the present study, about $75 \%$ faculties agreed that, theory syllabus can be completed through online, however less than $20 \%$ believed virtual demonstration of practical/clinical simulation is possible. Half the number of faculties find it possible to conduct sessional exam through online, however only $16.3 \%$ agree that university board exam should be conducted online.

The study found no significant difference while comparing the three Nepali universities regarding the dental faculties' perception on online education. It could be because of the curricular similarities and contextual teaching pattern among the faculties of different colleges. While analyzing the individual data; it was noticed that less number of faculties of TU colleges were taking online classes, and faculties of BPKIHS were more inclined towards use of online platforms for curricular and evaluation purposes.

COVID-19 outbreak has made dental education very difficult. Dentistry is basically concerned to accomplishment of skill however, lockdown is impeding the students to access practical, pre-clinical and clinical exercises. Faculties have been emphasizing the irreplaceable value of real classroom and clinical teaching/learning, allowing the real-time evaluation and feedback that are hard to generate in online forums. ${ }^{15}$ Taylor and Maor assessed the efficacy of online teaching in Australia. They cautioned that technological advances do not overshadow the educational judgment and traditional learning. ${ }^{16} \mathrm{O}^{\prime}$ Doherty et al. cited the key barriers of online education as: time constraints, poor technical skills, inadequate infrastructure, absence of institutional support/strategies and negative attitudes of the stakeholders. ${ }^{17}$ Solutions to these include improved faculty skill, incentives and reward for the development and delivery of online content, and improved institutional strategies. ${ }^{17}$

The online education should be a blend of various educational techniques and facilitation of flexible learning. Flexible learning offers choices in the educational environment and meets the needs of individual learning. ${ }^{18}$ The alternative online education approaches should replicate the technology that can have the lasting transformation of dental education. With the advancement of clinical simulations and tele-dentistry, the flexible approaches and solutions should be found. The effect of pandemic could be so profound that it may change the modalities that will educate and train future dentists. ${ }^{19}$

\section{CONCLUSION}

Nepali dental faculties had less exposure to online education system; the COVID-19 pandemic has paved the way for e-learning. Faculties emphasized the value of real classroom activities; however concur to incorporate online teaching as a component of learning process. While agreeing to complete the theory syllabus and conduct sessional exams as an alternative, many have shown strong reservations in carrying out practical/ clinical simulations and university exams online. Faculties of various universities showed consensus on perception towards online class. Faculties need to be more interactive with students emphasizing on assignments and feedback. Teachers' training on e-learning and institutional strategy for online education is recommended.

\section{ACKNOWLEDGEMENT}

The authors would like to thank all faculties who have participated in this online survey.

\section{REFERENCES}

1. Key messages and actions for COVID-19 prevention and control in schools. UNICEF. March 2020. https://www.who.int/docs/ default-source/coronaviruse/key-messages-and-actions-forcovid-19-prevention-and-control-in-schools-march-2020. pdf?sfvrsn=baf81d52_4.

2. Rimal HS. COVID-19: Challenges and opportunities in Nepal. Birat J Health Sci. 2020 Jan-April;5(1):11.

3. Ansari M. Covid-19 Pandemic and an urgent need of online learning approaches in Nepal and other developing nations. Birat J Health Sci. 2020;5(1)11:877-8.

4. Shrestha RM, Sujita, Kunwar N. Dentists in Nepal: A Situation Analysis. J Nep Health Res Counc. 2017 May-Aug;15(36):187-92.

5. Health Sector Emergency Response Plan. COVID 19 Pandemic. Government of Nepal Ministry of Health and Population. May 2020. https://www.who.int/docs/default-source/nepal-documents/novelcoronavirus/health-sector-emergency-response-plan-covid-19endorsed-may-2020.pdf?sfvrsn= ef831f44_2.

6. Shakya D, Mishra D, Gyawali R, Rimal S, Lama S, Yadav A, et al. COVID-19 Pandemic and BPKIHS: our situation, endeavors and future direction. J BP Koirala Inst of Health Sci. 2020:3(1):39-49.

7. Quinn B, Field J, Gorter R, Akota I, Manzanares MC, Paganelli C, et al. COVID-19: The immediate response of European Academic Dental Institutions and future implications for dental education. Eur J Dent Educ. 2020 May;eje.12542. https://doi.org/10.1111/eje.12542.

8. Halpin PA, Lockwood MK. The use of Twitter and Zoom videoconferencing in healthcare professions seminar course benefits students at a commuter college. Adv Physiol Educ. 2019 Jun;43(2):246-9.

9. Memon AR, Rathore FA. Moodle and online learning in Pakistani medical universities: An opportunity worth exploring in higher education and research. J Pak Med Assoc. 2018 Jul;68(7):1076-8.

10. El Tantawi MM, Abdelsalam MM, Mourady AM, Elrifae IM. e-Assessment in a limited-resources dental school using an open-source learning management system. J Dent Educ. 2015 May;79(5):571-83. 
11. Dahal N, Pangeni SK. Workshopping in online courses: Insights for Learning and assessment in higher education. International Journal of Multidisciplinary Perspectives in Higher Education. 2019;4(1):89-110.

12. Pangeni SK. Open and distance learning: Cultural practices in Nepal. European Journal of Open, Distance and e-Learning. 2017;19(2):3245.

13. Subedi S, Nayaju S, Subedi S, Shah SK, Shah JM. Impact of e-learning during COVID-19 pandemic among nursing students and teachers of Nepal. International Journal of Science and Healthcare Research. 2020 July-Sept; 5(3):68-76.

14. Atreya A, Acharya J. Distant virtual medical education during COVID-19: Half a loaf of bread. Clin Teach. 2020 Jun; 18:10.1111/ tct.13185.

15. Ferrel MN, Ryan JJ. The impact of COVID-19 on medical education. Cureus. 2020 Mar; 12(3):e7492.
16. Taylor $P$, Maor D. Assessing the efficacy of online teaching with the Constructivist on-line learning environment survey. Proceedings of the $9^{\text {th }}$ Annual Teaching Learning Forum, 2-4 February 2000. Perth: Curtin University of Technology. http://Isn.curtin.edu.au/tlf/tlf2000/ taylor.html.

17. O'Doherty D, Dromey M, Lougheed J. et al. Barriers and solutions to online learning in medical education: An integrative review. BMC Med Educ. 2018;18:130.

18. Shrestha A. Digital alternative for medical education. The Rising Nepal. 17 April 2020. https://risingnepaldaily.com/opinion/digitalalternative-for-medical-education.

19. Alzahrani SB, Alrusayes AA, Aldossary MS. Impact of COVID-19 pandemic on dental education, research, and students. Int J Health Sci Res. 2020;10(6):207-12. 